\title{
Pulmoner Tromboembolili Hastalarda Sağkalımı Etkileyen Faktörlerin Belirlenmesi
}

\section{Determination of Factors Affecting the Survival in Patients with Pulmonary Thromboembolism}

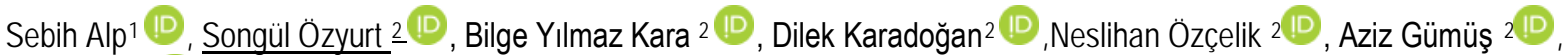 \\ Ünal Şahin
}

1 Gümüşhane Devlet Hastanesi Göğüs Hastalıkları Kliniği, Gümüşhane.

2 Recep Tayyip Erdoğan Üniversitesi Tıp Fakültesi Göğüs Hastalıkları AD, Rize.

Öz.

Amaç: Pulmoner tromboemboli tanısı ile yatırılarak tedavisi yapılan hastalarda yatışında ve taburcu edildikten sonraki 6 ay boyunca devam eden tedavi sürecinde ortaya çıkabilecek komplikasyonlar ve sağ kalımı etkileyen faktörlerin araştırıması amaçlanmıştır.

Materyal ve Metod: Çalışma Recep Tayyip Erdoğan Üniversitesi Tıp Fakültesi Eğitim ve Araştırma Hastanesi Göğüs Hastalıkları Kliniğinde pulmoner emboli tanısı ile yatırılarak takip ve tedavi edilen hastalarda yapıldı. 01/01/2014-01/12/2016 tarihleri arasında, spiral toraks anjio bilgisayarlı tomografisinde en az segmental pulmoner arterde dolum defekti saptanan erişkin hastalar çalışmaya alındı..

Bulgular: Çalışmaya alınan toplam 50 hastanın yaş ortalaması $73,04 \pm 13,313$ yıl ve 13'ü (\%26) erkek, 37'si (\%74) kadındı. Eksitus olanlarda nabız, Modifiye Geneva ve Wells skorları, pulmoner emboli şiddet indeksi ve basitleştirilmiş pulmoner emboli şiddet indeksi skorları sağ kalanlara göre yüksekti. Eksitus olanlarda hem RDW (Red Cell Distribution With) hem de 1. ve 5. Gün MCV (Mean Corpusculer Volum) ve hematokrit düzeyleri daha düşüktü. Eksitus olanlarda platelet sayısı daha yüksek iken 1. ve 5. gün kan total protein ve albümin düzeyleri düşük bulundu. ALP (Alkalen fosfataz)'ın 1. günde yüksekliği, 5. günde total bilirubin ve CRP (C-Reaktif Protein) yüksekliği mortalite ile ilişkili bulundu.

Sonuç: Çalışmamızda Basitleştirilmiş pulmoner emboli şiddet indeksi skorunun yüksekliği, taşikardi, 1. gün ve 5. gün bakılan hemoglobin, total protein, albümin düzeylerinin düşük olması, RDW düzeyi yüksekliği, ALP yüksekliği, 5. Günde WBC, CRP ve total bilirubin düzeylerinin hala yüksek seyretmesi mortalite ile ilişkili bulunmuştur.

Anahtar Kelimeler: Pulmoner Tromboembolizm, Mortalite

Abstract

Background: This study aimed to investigate the possible complications and factors affecting survival in hospitalized patients treated with the diagnosis of pulmonary thromboembolism, and the complications that may occur during the 6 months following discharge.

Methods: The study was performed in patients who were hospitalized and followed up with the diagnosis of pulmonary embolism and were treated at the Recep Tayyip Erdoğan University Faculty of Medicine Training and Research Hospital Chest Diseases Clinic. Adult Patients who were diagnosed with pulmonary thromboembolism at least segmental pulmonary artery filling defects at spiral thorax angiography computed tomography, between 01/01/2014 - 01/12/2016 were included in the study.

Results: The mean age of the patients was $73.04 \pm 13.313$ years and $13(26 \%)$ were male and 37 (74\%) were female. Pulse rate, Modified Geneva and Wells scores, pulmonary embolism severity index and simplified pulmonary embolism severity index scores were higher in those who died than that of survivors. Both the RDW (Red Cell Distribution With) and the 1st and 5th-day MCV (Mean Corpuscular Volume) and hematocrit levels were lower in those who died. While the number of platelets was higher in patients who died, blood total protein and albumin levels were found to be lower on the 1st and 5th days. The elevation of ALP (Alkaline phosphatase) on day 1 , total bilirubin on day 5, and CRP (C-Reactive Protein) elevation were associated with mortality.

Conclusion: High levels of simplified pulmonary embolism severity index score, tachycardia, hemoglobin, total protein, albumin levels, RDW level, ALP elevation, WBC, CRP and total bilirubin levels on the 5th day were all associated with mortality.

Key words: Pulmonary Thromboembolism, Mortality

\section{Sorumlu Yazar I \\ Corresponding Author}

\section{Songül Özyurt \\ Recep Tayyip Erdoğan Üniversitesi \\ Tıp Fakültesi \\ Göğüs Hastalıkları AD, Rize.}

e mail: drsongul@gmail.com 05534479778

\section{Geliş tarihi / Received: 11.02.2019}

\section{Kabul tarihi / Accepted:} 06.11.2019

\section{DOI: 10.35440/hutfd.525509}

Çalışmamız Dr. Sebih Alp'in 497476 no'lu Tıpta Uzmanlık Tezinden üretilmiştir

Çalışmamız UASK 2018 14-18 Mart 2018 Kaya Palazzo Resort Hotel Belek/Antalya Kongresinde sözlü sunum olarak sunulmuştur. 


\section{Giriş}

Pulmoner tromboemboli (PTE) mortalitesi ve morbiditesi yüksek, bazen zor tanı konulabilen, önlenebilir ve tedavi edilebilir bir hastalıktır. Yıllık insidans 1/1000 olup yaşla birlikte artmaktadır $(1,2)$. Derin ven trombozu (DVT) geçiren hastaların yaklaşık \%10'unda daha sonra PTE gelişmekte ve bu hastaların da yaklaşık \% 10'u kaybedilmektedir. Akut olayı izleyen ilk 3 ay içindeki ölüm oranları PTE tanısının prospektif araştıııması (PIOPED) çalışmasında $\% 15$, PTE kayıtlarının uluslararası toplanması (ICOPER) çalışmasında $\% 17,5$ bulunmuştur. PTE, tüm hastane ölümlerinin \%5-15'inden sorumludur. PTE geçiren ve yaşayan hastaların yaklaşık 2/3'ünde doğru tanı konulamamakta olup, bu hastalarda mortalite oranı \%30'lara ulaşmaktadır. PTE tanısı doğru olarak konulup, uygun tedavi yapıldığında bu oran \%3'e kadar düşebilmektedir (3).

Bu çalışmada kliniğimizde PTE tanısı ile yatırılarak tedavisi yapılan hastalarda yatışında ve taburcu edildikten sonraki 6 ay boyunca tedavi sürecinde ortaya çıkabilecek komplikasyonlar ve sağ kalımı etkileyen faktörlerin araştırılması amaçlanmıştır.

\section{Materyal ve Metot}

Çalışma Recep Tayyip Erdoğan Üniversitesi Tıp Fakültesi Eğitim ve Araştırma Hastanesi Göğüs Hastalıkları Kliniğinde pulmoner emboli tanısı ile yatırıarak takip ve tedavi edilen hastalarda yapıldı. 01/01/2014 - 01/12/2016 tarihleri arasında erişkin, spiral toraks anjio bilgisayarlı tomografi (BT)'de en az segmental pulmoner arterde dolum defekti saptanan, 13'ü erkek, 37'si kadın olmak üzere toplam 50 hasta çalışmaya dahil edildi.

Çalışma retrospektif planlanmış olup, dahil edime kriterleri; tanısı BT anjio ile kesinleştirimiş olmak, hastanede en az 7 gün yatmış olmak ve bu sürede ex olmamış olmak, 1. ve 7. Gün tetkiklerinde eksiklik olmamak, ekokkardiyografi (EKO) ve DVT bakılmış olmak, 6 aylık takipte telefon ile ulaşılabilmiş veya poliklinik kontrolüne gelmiş olmaktı.

Yatışından itibarenilk 7 gün içinde exitus olan hastalar, gebeler, veri tabanında takip/tetkikleri eksik olan hastalar, taburculuk sonrası kontrole gelmeyen ve ulaşlamayan hastalar, kreatinin yükseklği nedeniyle BT anjio çekilemeyen hastalar dışlandı.

Bu tarih aralığında toplam 150 hasta PTE tanısı ile servisimize yatırıldı. Çeşitli nedenler ile BT anjio çekilemeyen 20 hasta, yatış EKO bilgilerine ulaşılamayan 25 hasta, ilk 7 günde ex olan 10 hasta, 1 ve 7 . gün laboratuvar bulgularında eksiklikler olan 35 hasta, poliklinik kontrolüne gelmeyen ve telefon ile ulaşılamayan 10 hasta çalışmaya dahil edilmedi. Tüm kriterleri sağlayan 50 hasta ile çalışma yapıldı.

Olguların demografik özellikleri (yaş, cinsiyet, vücut kitle indeksi (BMI), sigara kullanım öyküsü), ek hastalıkları (Kronik Obstrüktif Akciğer Hastalığı (KOAH), bronşiektazi, immunsupresyon, Diyabetes Mellitus (DM), Hipertansiyon (HT), Koroner Arter Hastalığı (KAH), konjesif kalp yetmezliği (KKY), Serebrovasküler Olay (SVO), Kronik Böbrek Yetmezliği (KBY), malignite), risk faktörleri (yakın zamanda cerrahi, seyahat öyküsü, obezite, oral kontraseptif kullanımı, immobilite), yatış süreleri, maliyet ve mortaliteleri kaydedildi. Başvuru anında yapılan fizik muayene bulgularından solunum sayısı, tansiyon arteryel, vücut sıcaklığı, nabız, bilinç durumu, pulse oksimetri ile bakılan $\%$ saturasyon $\mathrm{O} 2$ değeri verilere eklendi. Arter kan gazı analizi yapılan olgulara ait pO2, pCO2, \% satürasyon $\mathrm{O} 2$ değeri, pH sonuçları not edildi. Acilde yapılan ve 7. Günde yapılan EKO bulguları ile bilateral alt extremite venöz dopler ultrasonografi (USG) sonuçları kaydedildi. 1-6 günlerde oda havasında pulse oksimetri ile bakılan \% saturasyon $\mathrm{O} 2$ düzeyleri kaydedildi. Olguların acil servis ve poliklinik başvurusu sırasında ve yatışın 1 . ve 5 . gününde bakılan hemogram, koagülasyon, troponin $T, D$ dimer, $\mathrm{C}$ reaktif protein (CRP), sedimentasyon, fibrinojen, genel biyokimya parametreleri kaydedildi. Başvuru sırasında çekilen posteroanterior akciğer grafisi ve toraks bilgisayarlı tomografi bulguları kaydedildi. Hastaneye yatışın ilk 24 saatinde yapılmış olan Wells ve Geneva klinik olasilık skorlama ile Wells kanama risk skorlaması, pulmoner emboli şiddet indeksi (PESI) ve basitleştirilmiş pulmoner emboli şiddet indeksi (sPESI) skorlaması sonuçları kaydedildi. Hastalar 6 aylık sürede telefonla aranarak bilgi alındı veya poliklinik kontrolü ile takip edildi.

Çalışmaya başlamadan önce yerel klinik etik kurul onayı alındı (1015/13).

\section{İstatiksel yöntemler}

İstatistiksel analiz için SPSS 22 istatistik programı kullanıldı. Verilerin değerlendirilmesinde sürekli değişkenler ortalama \pm standart sapma, kategorik değişkenler ise \% olarak ifade edildi. İki grubun karşılaştırılmasında studentT veya Mann-Whitney U testi kullanıldı. Değişkenler arasındaki ilişki Pearson veya spearmans korelasyon analizi ile incelendi. Kategorik değişkenlerin karşılaştırmasında Ki-Kare testi kullanıldı. $P<0.05$ değeri istatistiksel olarak anlamlı kabul edildi.

\section{Bulgular}

Çalışmaya toplam 50 hasta alındı. Hastaların yaş ortalaması 73,04 $\pm 13,31$ yıl idi. Hastaların demografik özellikleri, komorbid hastalıkları ve risk faktörleri Tablo 1'de gösterilmiştir.

Hastaların yaş ortalaması, başvuru sırasındaki semptom ve vital bulguları, arter kan gazı parametreleri, komorbid durumları, yatış maliyeti, klinik risk tahmin skorları (wells, Geneva), DVT durumu, bazı eko parametreleri, PESI ve sPESI skorları, yatışının 1. ve 5. gününde bakılan hemogram ve biyokimyasal parametreler ile mortalite ilişkisi incelendi.

Yaş ortalaması eksitus olanlarda $75,7 \pm 16,54$ yıl, sağ 
kalanlarda $72,38 \pm 12,54$ yıl olarak saptanmış ve bu durum istatistiksel olarak anlamlı bulunmamıştır $(p=0,564) .37$ kadın hastanın 9'unun (\%24,32), 13 erkek hastanın 1'inin $(\% 7,69)$ eksitus olduğu saptandı $(50 / 10, \% 20)$. Cinsiyete göre mortalite istatistiksel olarak anlamlı bulunmadı $(p=0,197)$.

Tablo 1. Hastaların Demografik Özellikleri, Komorbid Hastalıkları ve risk faktörleri.

$\mathrm{N} / \%$

\begin{tabular}{lr} 
Cinsiyet & \\
Erkek & $13(\% 26)$ \\
Kadin & $37(\% 74)$ \\
Komorbid Durumlar & \\
DM & $7(\% 14)$ \\
SVO & $5(\% 10)$ \\
HT & $31(\% 62)$ \\
KAH $\quad$ & $8(\% 16)$ \\
KKY & $5(\% 10)$ \\
Malignite & $6(\% 12)$ \\
Karaciğer hastallğı & $4(\% 8)$ \\
Immün supresyon & $4(\% 8)$ \\
Risk faktörleri & \\
Yakın zamanda cerrahi & $9(\% 18)$ \\
Seyahat öyküsü & $4(\% 8)$ \\
Obezite & $12(\% 24)$ \\
OKS kullanımı & $8(\% 16)$ \\
Mayor cerrahi & $7(\% 14)$ \\
İmmobilite & $17(\% 34)$ \\
Diğer & $23(\% 46)$ \\
\hline
\end{tabular}

DM: diabetes mellitus, SVO: Serebrovasküler Olay, HT: Hipertansiyon, KAH Koroner Arter Hastalığı, KKY: Konjestif Kalp Yetmezliği,

OKS: Oral Kontraseptif.

Hastaneye yatış sırasındaki vital bulguların mortalite ile ilişkisi Tablo 2' de gösterilmiş olup sadece ortalama nabız yüksekliği mortalite ile anlamlı ilişkili bulundu $(p=0,043)$. Hastaların yatıştaki semptomları ve komorbid durumları ile mortalite arasında istatistiksel olarak anlamlı ilişki saptanmadı.

Eksitus olanlarda yatış maliyeti sağ kalanlara göre belirgin yüksek olmasına rağmen bu durumun istatistiksel olarak anlamlı olmadığı görüldü $(p=0,280)$.

Modifiye Geneva (Cenevre) skorlaması ile Wells (Kanada) pulmoner tromboemboli klinik tahmin skorlaması ortalaması eksitus olanlarda daha yüksek saptandı, fakat bu yükseklik istatistiksel olarak anlamlı değildi. Hastaların acil serviste hesaplanan PESI ve SPESI skorları ile mortalite ilişkisi incelendi.
Tablo 2. Vital Bulgular ve Mortalite İlişkisi.

\begin{tabular}{|c|c|c|c|}
\hline Vital Bulgular & $\begin{array}{l}\text { Eksitus olan } \\
\text { hastalar }(\mathrm{N}=10) \\
\text { (Ortalama } \pm \mathrm{SD})\end{array}$ & $\begin{array}{l}\text { Yaşayan hastalar } \\
\text { (N=40) } \\
\text { (Ortalama } \pm \mathrm{SD})\end{array}$ & $\begin{array}{l}p \\
\text { (Student } \\
\text { T test) }\end{array}$ \\
\hline Ateş $\left({ }^{\circ} \mathrm{C}\right)$ & $36,73 \pm 0,44$ & $36,68 \pm 0,20$ & 0,735 \\
\hline $\mathrm{SS}(/ \mathrm{dk})$ & $26,20 \pm 8,47$ & $24,05 \pm 6,34$ & 0,467 \\
\hline $\mathrm{SKB}(\mathrm{mmHg})$ & $119,7 \pm 20,48$ & $125,7 \pm 19,46$ & 0,388 \\
\hline DKB $(\mathrm{mmHg})$ & $69,30 \pm 9,56$ & $76,35 \pm 10,14$ & 0,058 \\
\hline $\begin{array}{l}\text { Nabız } \\
\text { (atım/dk) }\end{array}$ & $107,7 \pm 13,97$ & $95,85 \pm 20,63$ & 0,043 \\
\hline
\end{tabular}

PESI skoru eksitus olanlarda ortalama 113, yaşayanlarda ortalama 97 olup, eksitus olan hastalarda daha yüksek olduğu görüldü. Fakat eksitus ve sağ kalan hastalar arasında PESI skoru açısından istatistiksel olarak anlamlı farklılık saptanmadı $(p=0,141)$. sPESI skoru ortalaması ise eksitus olanlarda 2.2, sağ kalanlarda 1.2 saptandı ve bu durum istatistiksel olarak anlamlı idi $(p=0,013)$ (Tablo 3).

Tablo 3. PESi ve sPESI Skorları ile Mortalite Iliskisi

\begin{tabular}{lllc}
\hline & $\begin{array}{l}\text { Eksitus olan hastalar } \\
(\mathrm{N}=10) \\
(\text { Ortalama } \pm \mathrm{SD})\end{array}$ & $\begin{array}{l}\text { Yaşayan hastalar } \\
(\mathrm{N}=40) \\
(\text { Ortalama } \pm \mathrm{SD})\end{array}$ & $\begin{array}{l}\mathbf{p} \\
\text { (Student T test) }\end{array}$ \\
\hline PESI & $113,70 \pm 34,53$ & $97,82 \pm 28,80$ & 0,141 \\
SPESI & $2,20 \pm 1,13$ & $1,20 \pm 1,09$ & 0,013 \\
\hline & & \\
\hline & PESI: Pulmoner Emboli Şiddet Indeksi, \\
SPESI: basitleştirimiş pulmoner emboli şiddet indeksi
\end{tabular}

Yatış anında değerlendirilen arter kan gazı (AKG) parametreleri ile mortalite arasında ilişkisi incelendiğinde eksitus olanlar ile sağ kalanlar arasında anlamlı farklılık saptanmadı.

1. gün bakılan ortalama WBC eksitus olanlarda daha düşük izlenirken, 5. gün ortalama WBC eksitus olanlarda mortalite ile anlamlı ilişkili olacak şekilde yüksek saptandı (sırasıyla $p=0,604 p=0,041$ ). 1. ve 5 . gün ortalama platelet sayıları eksitus olanlarda yüksek olmasına karşın anlamlı olarak değerlendirilmedi (sırasıyla $p=0,450 p=0,732$ ). 1 . ve 5. gün ortalama hemoglobin düzeyleri eksitus olanlarda daha düşük izlenmiş olup, mortalite ile ilişkili bulundu (sırasıyla $p=0,003 p=0,008$ ). 1. ve 5 . gün ortalama MCV ve 1 . ve 5 . gün hematokrit düzeyleri eksitus olanlarda daha düşük bulunmasına karşın mortalite ile anlamlı ilişki saptanmadı (sırasıyla $p=0,299 \quad p=0,067 \quad p=0,060$ $p=0,138$ ). 1. ve 5 . gün ortalama RDW düzeyleri eksitus olanlarda daha yüksek izlenmiş olup, mortalite ile ilişkili bulundu (sırasıyla $p=0,003 p=0,008$ ) (Tablo 4). Eksitus olan ve yaşayan hastalarda 1 . ve 5 . gün bakılan laboratuar parametleleri arasındaki ilişki Tablo 7'de görülmektedir.

Hem 1. gün hem de 5. gün bakılan total protein (sırasıyla $p=0,001 p=0,002$ ) ve albümin (sırasıyla $p=0,041 p=0,001$ ) ortalama düzeyleri eksitus olanlarda mortalite ile ilişkili 
olacak şekilde düşük bulundu. Hem 1. gün hem de 5. gün ortalama Alkalen fosfataz düzeyleri eksitus olanlarda yüksek olmasına karşın, sadece 1. gün yüksekliği mortalite ile ilişkili bulundu (sırasıyla $p=0,009 p=0,249$ ). Hem 1 . gün hem de 5 . gün ortalama total bilirubin (sırasıyla $p=0,758 p=0,001$ ) ve direk bilirubin (sırasıyla $p=0,263$ $p=0,079$ ) düzeyleri eksitus olanlarda yüksek olmasına karşın, sadece 5. gün ortalama total bilirubin düzeyi yüksekliği mortalite ile ilişkili bulundu. Eksitus olan hastalarda yatışında bakılan (1.gün) glukoz, üre, kreatinin, sodyum, klor ve ürik asit ortalama düzeyleri daha yüksek, potasyum, fosfor, magnezium, ALT, AST ve LDH ortalama düzeyleri ise daha düşük olmasına karşın mortalite ile ilişkili bulunmadı (Tablo 5).

Tablo 4. Hemogram 1. ve 5. gün Parametreleri ile Mortalite İlişkisi

\begin{tabular}{|c|c|c|c|}
\hline & $\begin{array}{l}\text { Eksitus olan hastalar } \\
(\mathrm{N}=10) \\
\text { (Ortalama } \pm \mathrm{SD})\end{array}$ & $\begin{array}{l}\text { Yaşayan hastalar } \\
(\mathrm{N}=40) \\
\text { (Ortalama } \pm \mathrm{SD})\end{array}$ & $\begin{array}{l}\mathbf{p} \\
\text { (Student } \\
\text { test) }\end{array}$ \\
\hline $\begin{array}{l}\text { WBC1 } \\
\text { (hc/uL) }\end{array}$ & $8610 \pm 3052$ & $9243 \pm 3369$ & 0,604 \\
\hline $\begin{array}{l}\text { WBC5 } \\
\text { (hc/uL) }\end{array}$ & $8020 \pm 4052$ & $5760 \pm 2751$ & 0,041 \\
\hline PLT1 (hc/uL) & $237510 \pm 116789$ & $209400 \pm 66619$ & 0,450 \\
\hline PLT5 (hc/uL) & $253900 \pm 107365$ & $243300 \pm 81682$ & 0,732 \\
\hline $\mathrm{Hb1}(\mathrm{g} / \mathrm{dl})$ & $11,43 \pm 1,87$ & $13,13 \pm 1,45$ & 0,003 \\
\hline $\mathrm{Hb5}$ (g/dl) & $10,81 \pm 1,37$ & $12,24 \pm 1,49$ & 0,008 \\
\hline MCV1 (fl) & $84,78 \pm 6,57$ & $86,79 \pm 5,12$ & 0,299 \\
\hline MCV5 (fl) & $82,69 \pm 5,21$ & $86,33 \pm 5,55$ & 0,067 \\
\hline HCT1 & $34,70 \pm 6,06$ & $38,95 \pm 4,16$ & 0,060 \\
\hline HCT5 & $33,48 \pm 3,34$ & $35,69 \pm 4,29$ & 0,138 \\
\hline RDW1 (\%) & $15,00 \pm 3,00$ & $12,21 \pm 1,17$ & 0,017 \\
\hline RDW5 (\%) & $16,03 \pm 2,73$ & $12,68 \pm 1,24$ & 0,004 \\
\hline \multicolumn{4}{|c|}{$\begin{array}{l}\text { Laboratuar parametrelerinin yanındaki } 1 \text { ve } 5 \text { sayıları 1. ve } 5 \text {. gün değerlerini } \\
\text { ifade etmektedir. }\end{array}$} \\
\hline \multicolumn{4}{|c|}{$\begin{array}{l}\text { Hastaların hem 1. hem de } 5 \text {. gün bakılan ortalama CRP } \\
\text { düzeyi eksitus olanlarda daha yüksek olup, } 5 \text {. gün yük- } \\
\text { sekliği mortalite ile ilişkili bulundu (sırasıyla p=0,234 } \\
\text { p=0,018). Ayrıca eksitus olanlarda } 1 \text {. ve } 5 \text {. gün bakılan } \\
\text { ortalama sedim, fibrinojen ve troponin I düzeyleri yüksek, } \\
\text { d-dimer düzeyleri ise düşük olup, mortalite ile anlamlı ilişki } \\
\text { saptanmadı (Tablo 6). } \\
\text { En az bir ekstremitede derin ven trombozu (DVT) bulgusu } \\
\text { olan } 24 \text { hastada 5'i (\%20) eksitus olduğu görüldü ve bu } \\
\text { durum istatiksel olarak mortalite ile ilişkili bulunmadı. } \\
\text { Bazı EKO parametreleri ile mortalite arasında ilişki bakıl- } \\
\text { dı. EF (ejeksiyon fraksiyonu) 'si düşük olan } 5 \text { hastadan } \\
\text { 2'si (\%40), D-septum eşlik etmeyen sağ boşlukları geniş } \\
\text { olan } 10 \text { hastadan 2'si (\%20), D-septum olan } 17 \text { hastadan }\end{array}$} \\
\hline
\end{tabular}

2'sinin eksitus olduğu görüldü. Bu sonuçlar ile mortalite arasında istatiksel ilişki saptanmadı.

\section{Tartışma}

Pulmoner Tromboemboli genel olarak her iki cinsiyette eşit olarak görülmektedir $(4,5)$.

Tablo 5. 1 ve 5. Gün bakılan Biyokimyasal Parametreler ve Mortalite Illişkisi

\begin{tabular}{llll}
$\begin{array}{l}\text { Eksitus olan } \\
\text { hastalar }(\mathrm{N}=10) \\
(\text { Ortalama } \pm \mathrm{SD})\end{array}$ & $\begin{array}{l}\text { Yaşayan hastalar } \\
(\mathrm{N}=40) \\
(\text { Ortalama } \pm \mathrm{SD})\end{array}$ & $\begin{array}{l}\mathbf{p} \\
(\text { Student } \\
\text { test })\end{array}$ & $\mathrm{T}$ \\
\hline $6,19 \pm 0,68$ & $7,02 \pm 0,63$ & $\mathbf{0 , 0 0 1}$
\end{tabular}

\begin{tabular}{|c|c|c|c|}
\hline $\begin{array}{ll}\text { T. } & \text { protein1 } \\
(\mathrm{g} / \mathrm{dl}) & \\
\end{array}$ & $6,19 \pm 0,68$ & $7,02 \pm 0,63$ & 0,001 \\
\hline $\begin{array}{ll}\text { T. } & \text { protein5 } \\
(\mathrm{g} / \mathrm{dl}) & \end{array}$ & $5,93 \pm 0,35$ & $6,40 \pm 0,69$ & 0,002 \\
\hline Albumin1 (g/dl) & $3,01 \pm 0,58$ & $3,79 \pm 0,38$ & 0,041 \\
\hline Albumin5 (g/dl) & $2,70 \pm 0,50$ & $3,40 \pm 0,42$ & $<0,001$ \\
\hline ALP1 (U/L) & $141,30 \pm 117,02$ & $81,51 \pm 39,50$ & 0,009 \\
\hline ALP5 (U/L) & $106,66 \pm 80,29$ & $83,84 \pm 47,76$ & 0,249 \\
\hline $\begin{array}{l}\text { T.bilirubin1 } \\
\text { (mg/dl) }\end{array}$ & $0,93 \pm 0,60$ & $0,87 \pm 0,45$ & 0,758 \\
\hline $\begin{array}{l}\text { T.bilirubin5 } \\
\text { (mg/dl) }\end{array}$ & $0,77 \pm 0,39$ & $0,45 \pm 0,21$ & 0,001 \\
\hline $\begin{array}{l}\text { D.bilirubin1 } \\
\text { (mg/dl) }\end{array}$ & $0,44 \pm 0,38$ & $0,29 \pm 0,16$ & 0,263 \\
\hline $\begin{array}{l}\text { D.bilirubin5 } \\
\text { (mg/dl) }\end{array}$ & $0,34 \pm 0,24$ & $0,18 \pm 0,08$ & 0,079 \\
\hline Üre (mg/dl) & $57,20 \pm 33,79$ & $47,98 \pm 20,23$ & 0,476 \\
\hline $\begin{array}{l}\text { Kreatinin } \\
(\mathrm{mg} / \mathrm{dl})\end{array}$ & $0,93 \pm 0,30$ & $0,83 \pm 0,40$ & 0,628 \\
\hline $\mathrm{Na}(\mathrm{mEq} / \mathrm{L})$ & $137,10 \pm 3,84$ & $136,95 \pm 2,97$ & 0,894 \\
\hline $\mathrm{K}(\mathrm{mEq} / \mathrm{L})$ & $3,99 \pm 0,62$ & $4,27 \pm 0,52$ & 0,151 \\
\hline $\mathrm{CL}(\mathrm{mg} / \mathrm{dl})$ & $104,10 \pm 5,38$ & $103,83 \pm 17,01$ & 0,961 \\
\hline $\mathrm{P}(\mathrm{mg} / \mathrm{dl})$ & $3,34 \pm 0,76$ & $3,47 \pm 0,81$ & 0,649 \\
\hline $\mathrm{Mg}(\mathrm{mg} / \mathrm{dl})$ & $1,91 \pm 0,24$ & $1,92 \pm 0,30$ & 0,939 \\
\hline ALT (U/L) & $27,40 \pm 24,65$ & $50,08 \pm 163,65$ & 0,666 \\
\hline AST (U/L) & $39,70 \pm 32,20$ & $88,45 \pm 381,64$ & 0,691 \\
\hline Ürik asit (mg/dl) & $7,3 \pm 3,07$ & $6,06 \pm 2,42$ & 0,177 \\
\hline CK (U/L) & $84,00 \pm 96,98$ & $107,15 \pm 167,73$ & 0,678 \\
\hline $\mathrm{LDH}(\mathrm{U} / \mathrm{L})$ & $413 \pm 295$ & $454 \pm 641$ & 0,843 \\
\hline
\end{tabular}

Laboratuar parametrelerinin yanındaki 1 ve 5 sayıları 1. ve 5 . gün değerlerini ifade etmektedir.

Tedavisiz olgularda PTE'nin mortalitesi yaklaşık \%30 civarında iken, tedavi edilenlerde mortalite \%8'in altına düşebilmektedir $(6,7)$. Mortalite genellikle malignite, kronik kardiyopulmoner komorbidite ve ileri yaş ile doğrusal olarak ilişkilidir $(7,8)$.

Çalışmamıza alınan olguların \%74'ü kadın olup literatürden farklı olarak PTE görülme oranı kadınlarda daha yüksek bulundu. Ayrıca kadın hastalarda istatistiksel olarak anlamlı olmamakla birlikte mortalite oranı daha 
yüksekti (sırasıyla \%24.32, \%7.69). Agarwall S ve ark. yapmış olduğu geniş katılımlı bir çalışmada benzer şekilde pulmoner embolinin kadın hastalarda erkeklere oranla daha mortal seyrettiği bildirilmiştir (9). Çalışmamızdaki hastaların yaş ortalaması $\% 73,04 \pm 13,31$ yıl olarak saptandı. Olgularımızın tamamı tedavi almasına rağmen literatürden farklı olarak mortalite (\%20) daha yüksek bulundu. Eksitus olan hastaların yaş ortalaması sağ kalanlara oranla daha yüksekti. Çalışmamızda gerek hastanede yatarak tedavi, gerekse 6 aylık takipleri boyunca kullanılan tedaviye bağlı kanama, ilaç yan etkisi gibi koplikasyonlar görülmedi.

Tablo 6. 1. ve 5. Günde bakılan bazı parametreler ile mortalite arasındaki ilişki

\begin{tabular}{llll}
\hline & $\begin{array}{l}\text { Eksitus olan } \\
\text { hastalar (N=10) } \\
\text { (Ortalama } \pm \text { SD) }\end{array}$ & $\begin{array}{l}\text { Yaşayan hasta- } \\
\text { lar (N=40) } \\
(\text { Ortalama } \pm \text { SD) }\end{array}$ & $\begin{array}{l}\text { p } \\
\text { (Student } \\
\text { test) }\end{array}$ \\
\hline CRP1 (mg/dl) & $6,97 \pm 4,72$ & $4,78 \pm 6,21$ & 0,234 \\
CRP5 (mg/dl) & $9,14 \pm 6,40$ & $3,63 \pm 6,37$ & 0,018 \\
SEDiM1(mm/h) & $48,90 \pm 35,70$ & $32,83 \pm 28,04$ & 0131 \\
SEDiM 5(mm/h) & $57,70 \pm 37,76$ & $34,73 \pm 26,32$ & 0,096 \\
D-dimer1(ng/ml) & $8129 \pm 9602$ & $14852 \pm 18896$ & 0,284 \\
D-dimer5(ng/ml) & $3000 \pm 2152$ & $3342 \pm 5254$ & 0,842 \\
Fibrinojen1 (mg/dl) & $472 \pm 168$ & $391 \pm 166$ & 0,176 \\
Fibrinojen5 (mg/dl) & $535 \pm 157$ & $447 \pm 188$ & 0,180 \\
Troponin I 1 & $0,58 \pm 1,07$ & $0,35 \pm 0,53$ & 0,329 \\
Troponin I 5 & $0,08 \pm 0,08$ & $0,05 \pm 0,07$ & 0,157 \\
\hline
\end{tabular}

PTE'de klinik semptom spektrumu, hastalı̆ı̆ şiddetine göre büyük farklııklar gösterdiği, güncel rehberlerde belirtilmiştir (10).Ülkemizdeki çeşitli merkezlerin verilerini içeren bir analizde bazı semptom ve bulguların görülme sıklıkları; nefes darlığı $(\% 50,7-81,5)$, batıcı göğüs ağrısı (\%55,1-84,8), hemoptizi (\%14-58,8), çarpıntı (\%10,1-50), öksürük $(\% 31,9-78,4)$, takipne $(\% 6,1-80)$, taşikardi $(\% 10,1-50)$, ral $(\% 25,6-53,2)$, siyanoz $(\% 4,1-38)$ ve DVT $(\% 16,9-56,4)$ olarak bildirilmiştir $(11,12)$. "Prospective Investigation of Pulmonary Embolism Diagnosis (PIOPED)" çalışmasında eşlik eden kardiyak ve pulmoner hastalığı olmayan PTE olgularında görülen semptomlar; nefes darlığı (\%73), plöretik ağıı (\%66), öksürük (\%37), ayakta şişme (\%26), hemoptizi (\%13), çarpıntı (\%10),"wheezing" (\%9) olarak bildirilmektedir (13). Duru ve ark. 205 hasta ile yaptıkları çalışmada PTE'de eşlik eden semtomlar dispne (\%85.3), göğüs ağrısı (\%61.4) ve öksürük (\%35.1) olarak tespit etmişlerdir (14). Çalışmamızda en sık üç semptom nefes darlığı, göğüs ağrısı ve senkoptu. Fakat literatürden farklı olarak hastalarımızda öksürük şikayeti daha azdı. Semptomların mortalite üzeri- ne etkisi olmadığı bilinmektedir. Bununla birlikte yapılan çalışmalarda senkopun masif pulmoner tromboemboli için belirleyici bir faktör olabileceği fakat mortalite ile ilişkili olmadığı görüşü de hakimdir (15).

PTE de görülen bulguların hiçbiri hastalığa spesifik değildir. Çok merkezli 2454 hastayı kapsayan ICOPER çalışmasında solunum sayısı 20 'nin üzerinde $\% 60$, kalp dakika vurusu 100'ün üzerinde \%40 olarak izlenmiştir (16). 2014 Avrupa Kardiyoloji Derneği (ESC), Akut Pulmoner Tromboemboli Tanı ve Tedavi Kılavuzu'nda akut pulmoner emboli hastalarının 30 gün içindeki erken mortalite riskini belirlemek ve tedavi planını ona göre yapmak için yeni bir sınıflama kullanıımaya başlamıştır (17). Bu sınıflandırmada hipotansiyon ve/veya şok tablosu ile başvuran hastalar yüksek risk grubunda değerlendirilmektedir. Hipotansif PTE olgularında erken hastane mortalitesi en az \%15'dir. Hemodinamik olarak stabil olan düşük riskli (nonmasif PTE'li) hastalarda erken mortalite \%1'in altındadır (17). Çalışmamızda eksitus olan ve yaşayan hastalar arasında ortalama vucut sıcaklığı benzer iken, eksitus olanlarda sistolik kan basıncı (SKB) ve diyastolik kan basıncı (DKB) ortalaması daha düşük, solunum sayıSı (SS) ortalaması daha yüksekti. Ayrıca başvuru esnasında nabız dakika atım sayısının yüksek olması mortalite ile ilişkili idi. Yaptığımı literatür taramasında ilk başvuru anındaki nabız ortalaması yüksekliği ile mortalite arasında ilişkiye değinen çalışmaya rastlanmadı.

Klinik semptom ve bulguların nonspesifik olmasına karşııık, hastaların taşıdıkları ve klinik çalışmalarda VTE ile ilişkili oldukları belirlenmiş bazı risk faktörleri ile birlikte değerlendirildiklerinde klinik olarak pulmoner emboli olasılığı tahmin edilebilmektedir. Modifiye Geneva (Cenevre) skorlaması ve Wells (Kanada) skorlaması, yaygın olarak kullanılan, geçerli kabul edilen klinik skorlama yöntemleridir $(18,19)$. Yapılan bazı çalısmalarda PTE nedeniyle ölen hastaların \%50'sinde tipik emboli kliniği saptanmamıştır. Ayrıca bu olgularda yapılan otopsi çalısmalarında ölmeden önce klinik skorlama ile yüksek olasılıklı PTE tanısı konulan hastaların \%60-65'inde embolinin var olmadığı da gösterilmiştir (20). Bu klinik skorlamaların mortalite üzerine etkisi olmadığı bilinmektedir. Çalışmamızda da Modifiye Geneva (Cenevre) skorlaması ve Wells (Kanada) skorlaması ile mortalite arasında literatür ile uyumlu olarak anlamlı ilişkili saptanmadı (21).

Akut PTE mortalitesi yüksek bir hastalık olması nedeniyle tedavisinde hızlı ve kesin risk değerlendirmesi önemlidir. Bu nedenle PTE'de prognoz değerlendirmede çeşitli klinik skorlamalar kullanılmaktadır. Güncel klavuzlarda mortalite riski yüksek ve düşük grubun ayrımında PESI ve SPESI kullanılmaktadır. sPESI'de parametrelerden herhangi biri pozitif olduğunda (Yaş >80, Kanser, Kronik kalp yetmezliği veya Kronik akciğer hastalığı, Nabız $\geq 110 / d k$, Sistolik kan basıncı $<100 \mathrm{mmHg}$ ) ölüm riski yüksek olarak değerlendirilmektedir (17). Aujesky ve ark. tarafından, 186 
hastanede PTE ile tedavi edilen 15,531 hastayı kapsayan, PESI skorlaması ile yapılan doğrulama çalışmasında, düşük riskli grupta (Sınıf I ve II) erken mortalite \%0,7 ve 1,2 iken, yüksek riskli grupta (sınıf III-V) ise sırasıyla $\% 4,8, \% 13,6, \% 25$ olarak bildirilmiştir (22).

Tablo 7. Exitus olan ve yaşayan grupta tekrarlayan ölçümdeki parametreler arasındaki ilişki

\begin{tabular}{|c|c|c|c|c|c|c|}
\hline & \multicolumn{2}{|c|}{ Yaşayan hastalar $(n=40)$} & \multicolumn{3}{|c|}{ Exitus olan hastalar $(\mathrm{n}=10)$} & \multirow[b]{2}{*}{$\mathrm{p}=^{*}$} \\
\hline & 1.Gün & 5.Gün & $\mathrm{p}=^{*}$ & 1.Gün & 5.Gün & \\
\hline D-Dimer & $14852 \pm 188896$ & $3342 \pm 5254$ & $<0.001$ & $8189 \pm 9602$ & $3000 \pm 2152$ & 0.113 \\
\hline Troponin & $0.35 \pm 0.53$ & $0.05 \pm 0.07$ & 0.001 & $0.58 \pm 1.07$ & $0.09 \pm 0.08$ & 0.166 \\
\hline Lökosit & $9243 \pm 3369$ & $5760 \pm 2751$ & $<0.001$ & $8610 \pm 3652$ & $8020 \pm 4052$ & 0.524 \\
\hline Trombosit & $2094000 \pm 66619$ & $243300 \pm 81682$ & 0.004 & $237510 \pm 116789$ & $253900 \pm 107365$ & 0.251 \\
\hline Hemoglobin & $13.1 \pm 1.45$ & $12.2 \pm 1.49$ & $<0.001$ & $11.4 \pm 1.9$ & $10.8 \pm 1.4$ & 0.106 \\
\hline RDV & $12.21 \pm 1.17$ & $12.68 \pm 1.24$ & $<0.001$ & $15.0 \pm 3$ & $16.0 \pm 2.7$ & 0.016 \\
\hline ALP & $81 \pm 39$ & $83 \pm 47$ & 0.692 & $141 \pm 111$ & $106 \pm 80$ & 0.449 \\
\hline T.Protein & $7.0 \pm 0.6$ & $6.4 \pm 0.6$ & $<0.001$ & $6.2 \pm 0.7$ & $5.9 \pm 0.4$ & 0.224 \\
\hline Albumin & $3.8 \pm 0.4$ & $3.4 \pm 0.4$ & $<0.001$ & $3.0 \pm 0.6$ & $2.7 \pm 0.5$ & 0.079 \\
\hline T.Bil & $0.87 \pm 0.45$ & $0.45 \pm 0.22$ & $<0.001$ & $0.93 \pm 0.61$ & $0.77 \pm 0.39$ & 0.249 \\
\hline D.Bil & $0.30 \pm 0.16$ & $0.18 \pm 0.08$ & $<0.001$ & $0.44 \pm 0.38$ & $0.34 \pm 0.25$ & 0.174 \\
\hline CRP & $4.78 \pm 6.21$ & $3.63 \pm 6.37$ & 0.186 & $6.97 \pm 4.72$ & $9.14 \pm 6.40$ & 0.085 \\
\hline Fibrinojen & $391 \pm 166$ & $447 \pm 188$ & 0.020 & $472 \pm 168$ & $535 \pm 157$ & 0.033 \\
\hline Sedimentasyon & $33 \pm 28$ & $34 \pm 26$ & 0.577 & $49 \pm 35$ & $58 \pm 38$ & 0.014 \\
\hline LDH & $454 \pm 641$ & $311 \pm 114$ & 0.163 & $413 \pm 295$ & $339 \pm 142$ & 0.343 \\
\hline
\end{tabular}

*paired samples T test

Yapılan birçok çalışmada sPESI'nin de mortaliteyi öngörmede PESI kadar etkin olduğu gösterilmiştir $(22,23,24)$. Çalışmamızda PESI ortalama skoru eksitus olanlarda yüksekti fakat anlamlı bulunmazken, sPESI ortalama skoru eksitus olanlarda anlamlı olacak şekilde yüksek bulundu. SPESI skorunun mortaliteyi belirlemede PESI skoru kadar etkin olduğu çalışmamız ile de desteklenmiştir. Bu nedenle pulmoner emboli tanılı hastalarda mortalitede belirleyici olması nedeniyle bu skorun mutlaka göz önünde bulundurulması gerekmektedir.

Arteriyel kan gazları ölçümünde PTE hastalarında genellikle hipoksi, hipokarbi ve respiratuvar alkoloz beklenir. Fakat hastaların \%35 kadarında normal saptanabilir (25). Kline JA. ve ark. 207 normotansif PTE tanilı hasta ile yaptıkları çalışmada; hipoksi, PTE ayırıcı tanısında bulunan hastalıklarda da sık olması ve PTE'lilerde her zaman mevcut olmamasına rağmen, hastalığın ağırlığı ile pozitif korelasyon gösterdiği gösterilmiştir (26). Çalışmamızda arterial kan gazı ortalama değerleri ile mortalite arasında anlamlı farklılık gözlenmedi, bu durumun örneklem sayısının az olması ile ilişkili olabileceği görüşündeyiz.

Diğer kardiyopulmoner hastalıklarda istenmeyen sonuçlarla ilişkili olmasına rağmen, akut pulmoner emboli tanılı hastalarda aneminin prognostik değeri üzerine sınırı kanıt bulunmaktadır. Donze J. ve ark. Amerika Birleşik Devletleri (ABD)'de çok merkezli 14276 primer tanısı PTE olan hastada yaptıkları çalışmada hastaların \%38,7 de anemi olduğunu tespit etmişlerdir. Bu çalışmada 30 günlük mortalite; anemi bulunan hastalarda \%13.7, anemi bulunmayan hastalarda \%6.3 olup bu çalışmada anemi, PTE ile başvuran hastalarda çok yaygın ve bağımsız olarak artan kısa dönem mortalite ile ilişkili bulunmuştur (27). Aujesky D ve ark. tarafından çok merkezli, geniş katılımlı bir çaIışmada yedi laboratuar değişkenleri (hemoglobin $<12 \mathrm{~g}$ / $\mathrm{dl}$, beyaz kan hücresi sayımı $<4000$ veya $>12.000 / \mathrm{mm} 3$, trombositler $<100.000 / \mathrm{mm} 3$, sodyum $<130$ veya $>150$ $\mathrm{mmol} / \mathrm{L}$, kan üre azot $\geqslant 11 \mathrm{mmol} / \mathrm{L}$ [30 mg / dl], arteriyel $\mathrm{pH}<7.25$ ve $\mathrm{PaCO} 2<25$ veya $>55 \mathrm{~mm} \mathrm{Hg}$ ), bağımsız bir şekilde ölüm ile ilişkili bulunmuştur (22).

RDW rutin kan parametreleri içinde bakılan ve kırmızı kan hücrelerinin heterojenitesini gösteren (anizositoz) yeni tanımlanmış bir belirteçtir. RDW'nin bazı olgularda artışı ve kimi çalışmalarda mortalite ile ilişkilendirilmesi muhtemelen inflamatuar durumlarda artması ile ilişkilidir $(28,29)$. Zorlu ve ark.'nın 2012 yılında yayınladıkları ve 136 akut PTE hastasını dahil ettikleri çalışmalarında RDW > \% 14.6 değerini mortaliteyi göstermede $\% 95.2$ duyarlılık ve $\% 53$ özgüllük ile anlamlı bulmuşlardır (30). Zhang ve ark. 1539 PTE hastasını dahil ettikleri retrospektif çalışmada ROC analizi ile saptanan değerlere göre hastalar RDW $>14.8$ ve $\leq \% 14.8$ olarak gruplandırımıştır. Çok değişkenli modelde RDW bağımsız değişken olarak mortaliteyi göstermede anlamlı bulunmuştur. RDW artışı daha çok oksidatif strese inflamatuar yanıt mekanizmasıyla açıklanmıştır (31).

Çalışmamızda literatür ile uyumlu 1. Ve 5 gün ortalama hemoglobin düşüklüğü 180 günlük mortalite ile anlamlı olacak şekilde ilişkili bulundu. Ayrıca çalışmamızda 5.günde bakılan WBC ortalama değeri eksitus olanlarda yüksekti ve 180 günlük mortalite ile ilişkiliydi. Benzer 
şekilde çalışmamızda literatürile uyumlu olarak 1 . ve 5 . günde ölçülen ortalama RDW değerleri eksitus olanlarda daha yüksekti ve bu durum 180 günlük mortalite ile ilişkili bulundu.

ALT ve AST; hepatoselüler hasar, bilirubin; hepatosellüler hasarla birlikte kolestaz durumlarında da artmaktadır. Albumin düzeyi ve protrombin aktivitesi ise karaciğerin sentez kapasitesini yansıtan testlerdir (32). Hipoalbüminemik hastalar serum albümin düzeyi normal olanlara kıyasla daha yüksek bir morbidite ve mortaliteye sahiptir (33). Bilirubin düzeyindeki artış infarkt sahasındaki eritrositin parçalanmasına bağlıdır. Karaciğerle ilgili bir ciddi problem olmadıgı sürece pulmoner embolide ALT ve AST düzeyleri belirgin olarak yükselmez. Ancak hipoksemi ağır ise karaciğerde harabiyete bağlı olarak bu enzimler yükselebilir $(32,34)$. Çalışmamızda ise ALT, AST ortalama düzeyleri eksitus olanlarda hem 1. gün hem de 5. günde daha düşük saptandı. Serum bilirubin düzeyleri eksitus olanlarda yüksek olmasına rağmen mortalite ile ilişkili bulunmadı.

Akut PTE nedeniyle hospitalize edilmiş olan geniş bir hasta serisinde yapılmış olan bir çalışmada, başvuru sırasındaki hiponatreminin 30 gün içindeki mortalite ve yeniden hastane başvurusu ile ilişkili bulunmuştur (35). Çalışmamızda ise ortalama serum sodyum düzeyi ölenlerde daha yüksek bulunmuştur. Nitekim yaşlı olmaları ve eşlik eden pek çok hastalığa sahip olmaları nedeniyle, PTE'li hastaların çoğunda, malnutrisyon sıklıkla bulunmaktadır, miyokard hasarı ve RVD'e bağlı salgılanan anormal katekolamin ve nörohormonlara bağlı olarak serum sodyum düzeyinde anormallikler meydana gelebilmektedir.

Albumin negatif akut faz reaktanıdır. Birçok akut infektif ve inflamatuvar hastalıkta serum düzeyi azalır. Albumin düşüklüğü bazı hastalıklarda kötü prognoz ve artmış mortalite ile ilişkilidir. Literatür taramasında kritik hastalık durumunda serum total protein ve albümin düzeyi düşüklüğünün mortalite ile ilişkili olduğunu vurgulayan çalışmalar mevcuttur (33). Çalışmamızda da literetür ile uyumlu olarak, 1. ve 5. gün ortalama serum total protein ve albümin düzeyleri ölen hastalarda anlamlı düşüş saptandı.

Yüksek CRP'nin venöz tromboembolizm riski ile ilişkili olduğu bildirilmiştir (36). Yaptığımız incelemede; yüksek CRP'nin PTE'de prognozla ilişkilisini vurgulayan çalışma azdır. Abul Y. ve ark. (37) Akut PTE tanılı 56 hasta ile yaptıkları çalışmada, hastalar taburcu olduktan sonra 36 aylık takipte, mortalite oranları CRP ve troponin T düzeyleri yüksek olan hastalarda daha yüksek bulmuşlardır. Kardiyak enzimlerin, sol ventrikül disfonksiyonunu yansıtan, sağ ventrikülün aşırı yüklenmesine bağlı olarak miyokard kasından salınan ve miyokard hasarını gösteren spesifik ve sensitiv belirteçler olduğu bilinmektedir. Çeşitli meta-analizlerde troponin düzeyi yüksek bulunan hastalarda mortalite oranları, troponin düzeyi normal olan has- talara göre anlamlı olarak yüksek bulunmuştur (38). ÇaIışmamızda 1. gün CRP ortalama düzeyi eksituslarda daha yüksek olmasına rağmen mortalite arasında anlamlı ilişki bulunmazken, 5. gün ortalama CRP yüksekliği literatür ile uyumlu olarak mortalite ile ilişkiliydi. Ayrıca literatürden farklı olarak çalışmamızda 1. ve 5 . gün ortalama serum troponin $T$ düzeyi ile mortalite arasında anlamlı ilişki saptanmadı.

Çalışmamızda çeşitli kısıtılıklar mevcuttur. Retrospektif bir çalışma olması nedeniyle veriler hastane kayıtlarına dayanmaktadır. Hasta sayısının az olması genel popülasyonu yansitmayabilir.

Sonuç olarak pulmoner tromboemboli tanı ve tedavideki gelişmelere rağmen mortalite ve morbiditesi yüksek bir hastalıktır. Rutin, kolay uygulanabilir fizik muayene ve laboratuar bulguları mortaliteyi tahmin etmede yararlı olabilir.

Çalışmamızla ilgili herhangi bir çıkar çatışmamız bulunmamaktadır

\section{Kaynaklar}

1. Rosendaal FR. Risk factors for venous thrombotic disease. Thromb Haemost. 1999; 82: 610-9.

2. Palevsky HI, Kelley MA, Fishman AP. Pulmonary thromboembolik disease In: Fishman AP, Elias JA, Fishman JA, Grippi MA (eds). Fishman's Pulmonary Diseases and Disorders. New York: International Edition Mc Graw Hill, 1998; 1297-329.

3. White $\mathrm{RH}$. The epidemiology of venous thromboembolism. Circulation. 2003; 107 (Suppl1):14-8.

4. Tormene D, Ferri V, Carraro S, Simioni P. Gender and the riskof venous thromboembolism. Semin Thromb Hemost 2011;37: 193-8.

5. Santosa F, Moysidis T, Moerchel C, Kröger K, Bufe A. Pulmonary embolismin young people: Trends in Germany from 2005 to 2011. Hamostaseologie. 2014;34: 88-92.

6. Keller K, Beule J, Balzer JO, Dippold W. Evaluation of Risk Stratification Markers and Models in Acute Pulmonary Embolism: Rationale and Design of the MARS-PE (Mainz Retrospective Study of Pulmonary Embolism) Study Programme. Acta Medica (Hradec Kralove). 2018;61(3):93-7.

7. Nijkeuter M, Söhne M, Tick LW, Kamphuisen PW, Kramer MH, Laterveer $\mathrm{L}$, et al. The natural course of hemodynamically stable pulmonary embolism. Chest. 2007;131:517-23.

8. British Thoracic Society Standards of Care Committee Pulmonary Embolism Guideline Development Group. British Thoracic Society guidelines for the management of suspected acute pulmonary embolism. Thorax 2003;58: 470-84.

9. Agarwal S, Clark D 3rd, Sud K, Jaber WA, Cho L, Menon V. Gender Disparities in Outcomes and Resource Utilization for Acute Pulmonary Embolism Hospitalizations in the United States. Am J Cardiol. 2015;116(8):1270-6.

10. Arseven, O., Ekim, N., Müsellim, B., Oğuzülgen, IK., Okumuş, N. G., Öngen, $G$. ve ark Pulmoner embolizm tanı ve tedavi uzlaşı raporu. Türk toraks dergisi, 2015:1-80

11. Özsu $S$, Özlü T, Bülbül Y. Ulusal verilerle pulmoner tromboemboli. Tüberküloz ve Toraks Dergisi 2009; 57: 466-82.

12. Erbaycu AE, Tuksavul F, Uçar H, Güçlü SZ. Kırk dokuz pulmoneremboli olgusunun retrospektif değerlendirilmesi. İzmir Göğüs Hastanesi Dergisi. 2004;18: 113-8.

13. PIOPED Investigators. Value of the ventilation/perfusion scan in acute pulmonary embolism. Results of the prospective investigation of pulmonary embolism diagnosis (PIOPED). JAMA. 1990; 263: 2753-9.

14. Duru S, Ergün R, Dilli A, Kaplan T, Kaplan B, Ardıç S, et al. Clinical, laboratory and computed tomography pulmonary angiography results in pulmonaryembolism: retrospective evaluation of 205 patients. Anadolu Kardiyoloji Dergisi. 2012; 12: 142-9. 
15. Omar HR, Mirsaeidi M, Weinstock MB, Enten G, Mangar D, Camporesi EM. Syncope on presentation is a surrogate for submassive and massive acute pulmonary embolism. Am J Emerg Med. 2018;36(2):297-300.

16. Goldhaber SZ, Visani L, De Rosa M. Acute pulmonary embolism: Clinical outcomes in the International Cooperative Pulmonary Embolism Registry (ICOPER). Lancet. 1999;353:1386-9.

17. Konstantinides SV, Torbicki A, Agnelli G, Danchin N,Fitzmaurice D, Galiè $\mathrm{N}$, et al; The Task Force for the Diagnosisand Management of Acute Pulmonary Embolismof the European Society of Cardiology (ESC) Endorsedby the European Respiratory Society (ESC). 2014 ESCGuidelines on the diagnosis and management of acutepulmonary embolism. Eur Heart $\mathrm{J}$. 2014; 35: 3033-69,3069a-3069k

18. Wells PS, Anderson DR, Rodger M, Stiell I, Dreyer JF, Barnes D, et al. Excluding pulmonary embolism at the bedside without diagnostic imaging: management of patients with suspected pulmonary embolism presenting to the emergency department by using a simple clinical model and $d$ dimer. Ann Intern Med. 2001; 135: 98-107.

19. Ceriani E1, Combescure C, Le Gal G, Nendaz M, Perneger T, Bounameaux $\mathrm{H}$, et al. Clinical prediction rules for pulmonary embolism: a systematic review and meta-analysis. J Thromb Haemost. 2010; 8: 957-70.

20. Palla A, Petruzzelli $S$, Donnamaria $V$, Giuntini $C$. The role of suspicion in the diagnosis of pulmonary embolism. Chest. 1995;107:21-4.

21. Ishimaru $N$, Ohnishi $H$, Yoshimura $S$, Kinami $S$. The sensitivities and prognostic values of the Wells and revised Geneva scores in diagnosis of pulmonary embolism in the Japanese population. Respir Investig. 2018;56(5):399-404.

22. Aujesky D, Obrosky DS, Stone RA, Auble TE, Perrier A, Cornuz J, et al. Derivation and validationof a prognostic model for pulmonary embolism. AmJ Respir Crit Care Med 2005;172:1041-6.

23. Jiménez D, Aujesky D, Moores L, Gómez V, Lobo JL, Uresandi F, et al. Simplification of thepulmonary embolism severity index for prognostication inpatients with acute symptomatic pulmonary embolism. Arch Intern Med 2010;170:1383-9

24. Righini M, Roy PM, Meyer G, Verschuren F, Aujesky D, Le Gal G. The Simplified PulmonaryEmbolismSeverity Index (PESI): validation of a clinical prognosticmodel for pulmonary embolism. J Thromb Haemost. 2011;9: 2115-7.

25. Hauel NH, Nar H, Priepke H, Ries U, Stassen JM, WienenW. Structurebased design of novel potent nonpeptide thrombininhibitors. J Med Chem. 2002; 45: 1757 .

26. Kline JA, Hernandez-Nino J, Newgard CD, Cowles DN, Jackson RE, Courtney DM. Use of pulse oximetry to predict in-hospital complications in normotensive patients with pulmonary embolism. Am J Med. 2003; 115: 203-8.

27. Donzé J Labarère J, Méan $M$, Jiménez D, Aujesky D. Prognostic importance of anaemia in patients with acute pulmonary embolism. Thromb Haemost. 2011;106(2):289-95.

28. Dabbah S, Hammerman H, Markiewicz W, Aronson D: Relation between red cell distribution width and clinical outcomes after acute myocardial infarction. Am J Cardiol. 2010;105(3):312-7.

29. Rhodes CJ, Wharton J, Howard LS, Gibbs JSR, Wilkins MR: Red cell distribution width outperforms other potential circulating biomarkers in predicting survival in idiopathic pulmonary arterial hypertension. Heart. 2011:97(13):1054-60.

30. Zorlu A, Bektasoglu G, Kukul Guven FM, Dogan OT, Gucuk E, Refiker Ege $M$, et al: Usefulness of admission red cell distribution width as a predictor of early mortality in patients with acute pulmonary embolism. Am J cardiol. 2012;109(1):128-34.

31. Zhang $\mathrm{Z}, \mathrm{Xu} \mathrm{X}, \mathrm{Ni} \mathrm{H}$, Deng $\mathrm{H}$ : Red cell distribution width is associated with hospital mortality in unselected critically ill patients. Journal of thoracic disease. 2013;5(6):730-6.

32. Sonsuz A. Karaciğer Fonksiyon Bozukluklarına Klinik Yaklaşım. iÜ. Cerrahpaşa Tıp Fakültesi Sürekli Tıp Eğitimi Etkinlikleri.2007: 6978.

33. Marik P.E. The treatment of hypoalbuminaemia in the critically ill patient Heart and Lung. 1993;22:166-70.

34. Harold IP, Mark AK, Alfred PF. Pulmonary thromboembolic disease.n :Fishman AP(ed). Fishman's Pulmonary Disease and Disorders. Ed: AP Fishman. Mc Graw Hill Newyork 1998; pp: 1297-1329.

35. Scherz N, Labarere J, Mean M, Ibrahim SA, Fine MJ, Aujesky D. Prognostic importance of hyponatremia in patients with acute pulmonary embolism. Am J Respir Crit Care Med 2010; 182: 1178-83.

36. Zacho J, Tybjaerg-Hansen A, Nordestgaard BG. C-reactive protein and risk of venous thromboembolism in the general population. Arterioscler Thromb Vasc Biol. 2010;30:1672-8.
37. Abul Y, Karakurt S, Özben B, Toprak A, Çelikel T. C-reaktive protein in acute pulmonary embolism. J Investig Med. 2011; 59 (1): 8-14.

38. Becattini $C$, Vedovati MC, Agnelli $G$. Prognostic value of troponins in acute pulmonary embolism: a meta analysis. Circulation. 2007;116:427-33. 